\title{
LITERACY, TRUST AND 401(K) SAVINGS BEHAVIOR
}

\author{
Julie R. Agnew, Lisa Szykman, Stephen P. Utkus, and Jean A. Young* \\ CRR WP 2007-10 \\ New version posted: April 2009 \\ Released: May 2007 \\ Draft Submitted: March 2007
}

\author{
Center for Retirement Research at Boston College \\ Hovey House \\ 140 Commonwealth Avenue \\ Chestnut Hill, MA 02467 \\ Tel: 617-552-1762 Fax: 617-552-0191 \\ www.bc.edu/crr
}

* Julie R. Agnew is an assistant professor of finance and economics at the College of William and Mary. Lisa Szykman is an associate professor of marketing at the College of William and Mary. Stephen P. Utkus is the Principal of the Vanguard Center for Retirement Research. Jean A. Young is a research analyst at the Vanguard Center for Retirement Research. The research reported herein was performed pursuant to a grant from the U.S. Social Security Administration (SSA) funded as part of the Retirement Research Consortium. The opinions and conclusions expressed are solely those of the authors and do not represent the opinions or policy of SSA, any agency of the Federal Government, Boston College, the College of William and Mary, or Vanguard. We would like to thank Olivia Mitchell for her comments. We would also like to thank Matthew Woodall for his excellent research assistance.

(C) 2009, by Julie R. Agnew, Lisa Szykman, Stephen P. Utkus, and Jean A. Young. All rights reserved. Short sections of text, not to exceed two paragraphs, may be quoted without explicit permission provided that full credit, including $(\odot$ notice, is given to the source. 


\begin{abstract}
Financial literacy and trust in financial institutions - two qualitative variables missing from standard neoclassical or behavioral models of decision-making - are strongly related to 401(k) saving behavior. In voluntary enrollment settings, financial literacy has a larger marginal effect on saving than does a sizeable increase in income. In automatic enrollment settings, low levels of literacy and trust are linked to the decision of employees to quit their savings plan. While it cannot be disputed that automatic enrollment is a very successful intervention, our results suggest that there still may be opportunities to improve savings rates among employees with low literacy and trust characteristics. These findings underscore the need for remedial education and plan design strategies, as well as the importance of a broader specification for models of savings behavior.
\end{abstract}




\section{Literacy, Trust and 401(k) Savings Behavior}

Julie R. Agnew, Lisa Szykman, Stephen P. Utkus, and Jean A. Young

\section{Introduction}

Over the past fifteen years, a substantial body of 401(k) savings research has posited a number of reasons why employees participate (or fail to participate) in voluntary 401(k) arrangements. These include neoclassical explanations, such as employee budget constraints, the incentive effect of employer matching contributions, and the desire by employees for tax-deferred savings, as well as behavioral explanations, including procrastination, peer effects, and choice overload. Meanwhile, recent efforts to understand household financial decision-making more broadly have focused on the critical role played by financial literacy. In addition, in the context of banking and other financial decisions, the role of trust has become a focus, particularly among low-income households. Overall it would appear that financial decision-making is influenced by a complex set of factors, yielding to both neoclassical and behavioral explanations.

Our current effort uses a very unique dataset that combines both survey and administrative data and is the first attempt to extend the issues of financial literacy and trust to the domain of 401(k) savings behavior. Moreover, our research takes place in the context of a significant change occurring in the nature of 401(k) plan design, motivated by behavioral findings regarding employee inertia and the importance of default and framing effects on employee savings. Increasingly, employers offering 401(k) plans are availing themselves of a plan design strategy known as automatic enrollment, under which eligible workers have 401(k) contributions automatically deducted from their paychecks, with the legal right to opt-out if they choose. ${ }^{1}$ This reframing of the savings 
decision, from a positive to a negative election, improves plan participation rates dramatically. At the same time, it is still the case that among certain demographic groups within the population of eligible workers, as many as $20 \%$ choose to exercise their optout rights and quit an automatic enrollment plan (Madrian and Shea, 2001; Nessmith, Utkus and Young, 2007).

As a result, two types of non-savers have emerged today in the U.S. 401(k) system: "non-joiners," those who fail to join voluntary 401(k) arrangements; and "quitters," those who exercise their opt-out rights under an automatic enrollment regime. This development raises an intriguing set of questions about the dynamics of 401(k) savings behavior. Are quitters (of automatic enrollment plans) fundamentally different from non-joiners (of voluntary plans)? Do neoclassical models help explain the variations between the two types of non-savers—or are broader questions of financial literacy or trust important as well? The goal of this paper is to paint a more complete picture of the 401(k) savings decision in the context of both voluntary and automatic enrollment plans. We rely on administrative and survey data drawn from three large firms sponsoring 401(k) plans, two offering automatic enrollment plans and one offering a voluntary enrollment plan. The survey data permit us to delve into the psychological motivations behind employee savings decisions, which would not be possible with administrative data alone. This unique combination is an important distinguishing feature of this study.

We find that two measures not included in prior research - financial literacy and trust in financial institutions -play a critical role in shaping employee savings behavior. In voluntary enrollment 401(k) plans, the marginal effects of literacy are substantial, and 
are arguably more powerful than a sizeable increase in income. Under automatic enrollment, low levels of both literacy and trust are strongly linked to the decision by an employee to quit their employer's savings plan. While automatic enrollment, designed as a remedial strategy to address behavioral biases such as procrastination, is an extremely successful intervention that increases participation across demographic groups, our results suggest that despite its overwhelming success, there still may be an opportunity to improve savings among a vulnerable subgroup of employees with low literacy and low trust characteristics.

These findings underscore the fact that even the highly successful reframing strategies, such as automatic enrollment, can have limitations in the face of substantial problems of illiteracy and mistrust. They highlight the importance of financial literacy and trust-building efforts, principally through communications and education programs, as a potential remedy. In addition, in light of research suggesting the importance of learning in financial decision-making ${ }^{2}$, our results suggest the need for a more persistent approach to automatic enrollment, such as the periodic re-enrollment of quitters, as they gain over time general lifetime financial experience and specific knowledge of 401(k) saving. Finally, given the recent economic events, low levels of trust in financial institutions may lead more employees to decide to not participate in a 401(k) savings plan. This paper is organized as follows. After a literature review in the next section, the third section of the paper turns to our administrative data, and the fourth to our survey instrument and measures of literacy and trust. The fifth section presents our econometric analysis, and a final section concludes. 


\section{Literature Review}

Most prior research on the 401(k) savings decision has been centered on straightforward neoclassical lifecycle models, using either administrative or survey data, and considering employee choices in a voluntary enrollment setting. ${ }^{3}$ Overall, the research using administrative data suggests that three key demographic variables are positively related to 401(k) participation - income, age and job tenure. Several theories have been suggested to explain the positive income and plan participation relationship. In particular, low-income households may participate less than higher income households because they are more likely to be financially constrained (i.e., a simple positive elasticity of saving with respect to income); they face lower (or negative) tax rates and derive little (or no) tax benefit from 401(k) saving; or they need to save less because of the progressive benefits structure of Social Security. In terms of age, a general lifecycle model suggests age-related variation in savings. As well, as employees age, the importance of savings may become more salient, making participation in a retirement plan more likely. Job tenure is also strongly linked to 401(k) plan participation. One reason may be that longer-tenured employees may find plan participation more attractive due to the vesting of benefits over time; another may be growing familiarity over time with the employer's retirement plan.

Workplace financial education programs have been linked to improved 401(k) savings outcomes (Bernheim and Garrett, 1996; Nyce, 2005), although financial literacy levels per se have not been incorporated in 401(k) savings models. Outside the domain of 401(k) plans, Moore (2003) finds that individuals with lower levels of financial literacy are less likely to engage in positive financial behaviors (e.g., paying bills on time, 
budgeting and tracking expenses, and saving/investing money out of every paycheck). Moore (2003) also suggests that individuals with low financial literacy are naïve when it comes to evaluating financial options. Lusardi and Mitchell (2006) demonstrate that those with higher financial literacy are more likely to save and invest in more complex assets, using data from older households in the Health and Retirement Study. Using special modules from the Dutch National Bank Household Survey, van Rooij, Lusardi and Alessi (2007) find that individuals with low literacy are significantly less likely to invest in stocks. In the 401(k) domain, using an experimental approach, Agnew and Szykman (2005) suggest that individuals with lower levels of financial literacy are more likely to take a default plan investment option when making asset allocations than individuals with higher levels of financial literacy.

Knowledge of a retirement plan's specific features, as opposed to measures of general financial literacy, may also be related to increased saving behavior. Choi, Laibson and Madrian (2005) found that only 21\% of 401(k) participants contributing below their plan's match threshold knew their plan's match rate, compared to $41 \%$ of those above the match threshold. Furthermore, Chan and Stevens (2006) find that knowledgeable participants are five times more responsive to plan features than the average individual.

Finally, a well-known stream of research supports the influence of behavioral biases on $401(\mathrm{k})$ decisions and suggests that employees may not be behaving as standard neoclassical decision agents. ${ }^{4}$ The automatic enrollment findings noted above indicate that a simple reframing of the 401(k) savings decision from a positive to a negative election can elicit substantially higher plan participation rates. Other researchers have 
noted other behavioral biases, including procrastination in a variety of other retirement plan decisions (Choi, Laibson, Madrian and Metrick, 2006), the fact that "choice overload" (as measured by the number of plan investment options) may discourage plan participation (Sethi-Iyengar, Huberman, and Jiang, 2004), and the effect of peer groups on an individual's own saving behavior (Duflo and Saez, 2003).

In this paper, we examine the role of trust, a behavioral factor that has not been previously addressed in the context of retirement savings choices and may be either rational or irrational. ${ }^{5}$ A distrust of financial institutions has been shown to influence general financial behavior, particularly among households in lower socio-economic strata. Poorer individuals have a culture of distrust of financial institutions and consciously avoid doing business with them (Bertrand, Mullainathan, and Shafir, 2006; Szykman, Rahtz, Plater, and Goodwin 2005). In a related focus group conducted by Szykman et al. (2005), respondents expressed feelings of alienation as well as an underlying belief that banks cannot be trusted to do the right thing. The respondents also stated that they avoided doing business with banks because of these perceptions. Finally, Guiso, Sapienza and Zingales (2007) found that lack of trust can explain why some people do not invest in the stock market. ${ }^{6}$ They find that countries with low stock participation rates have low trust levels.

Broadly speaking the prior literature on 401(k) savings behavior advances three distinct theories of individual decision-making:

Hypothesis 1: Neoclassical Agents. Under this theory, non-savers, regardless of the type of retirement plan offered, are viewed as forward-looking, rational agents. Their decision not to save in a 401(k) plan is rationally explained by income-related budget 
constraints, their own preferences for tax-deferred saving, and by a recognition that saving is unnecessary given the presence of Social Security benefits.

Hypothesis 2: Information Costs. In this model, non-savers may be impeded by a lack of information on basic financial concepts and plan features, as well as by the transaction costs needed to accumulate that information. They are rational agents impeded by information or financial literacy constraints.

Hypothesis 3: Behavioral Biases. Under behavioral theories of 401(k) decisionmaking, non-savers are impeded by psychological biases such as procrastination that may interfere with a purely rational assessment of retirement savings choices. Trust, whether rationally or irrationally based, is another factor that may influence behavior.

These theories are not necessarily mutually exclusive. For example, List (2004) finds that prospect theory adequately explains the behavior of inexperienced consumers, whereas those with intense market experience react more in line with neoclassical predictions. It is thus possible that elements of 401(k) saving behavior are explained by all three theories. Indeed, both the prior empirical evidence, as well as our new findings, suggest that a complex set of factors — rational, information-constrained and behavioralare all linked to 401(k) savings.

\section{Administrative and Survey Data}

Our current study is based on administrative and survey data from three 401(k) savings plans. Administrative data, including employee demographics and plan behavior, were extracted from Vanguard recordkeeping systems under restricted access conditions in mid-2006. ${ }^{7}$ The three plans drawn from Vanguard systems were chosen based on 
similar plan features, including the availability of employer matching contributions and the presence of similar-sized investment menus, in order to minimize the impact of planspecific design variation. ${ }^{8}$ What distinguishes the plans from one another is their use of automatic versus voluntary enrollment. Plans A and B have an automatic enrollment feature: eligible employees receive communication materials notifying them that they are automatically enrolled after a given period following employment—90 days in the case of Plan A, two months in the case of Plan B. Plan C is a voluntary enrollment plan; eligible employees receive communication materials inviting them to join the plan upon employment.

Table I summarizes important plan characteristics. Plan A and Plan B instituted automatic enrollment in 2003 and 2001, respectively, for new-hires only. As a result, our analysis is restricted to new hires in the three plans based on the "cut-off date" when automatic enrollment was introduced in each plan. (For the voluntary plan, we set the new hire cut-off date to equal Plan B.) Our sample size for the administrative data set, from which our survey respondents are drawn, is 9,523.

\section{Table I here}

As expected based on prior studies, the automatic enrollment plans have higher participation rates than the voluntary enrollment plan - 84\% (Plan A) and 78\% (Plan B) versus $64 \%$ (Plan C). ${ }^{9}$ This difference is even more striking given the substantially lower incomes of the participants in the automatic enrollment plans (mean salary of $\$ 37,994$ for Plan A and \$34,383 for Plan B versus $\$ 69,803$ for Plan C). We believe that these descriptive statistics underscore the strong effect of automatic enrollment on savings choices. 
To obtain our literacy and trust measures, we administered a telephone survey to a random subset of the new hires drawn from the administrative data set. ${ }^{10}$ Panel A of Table II presents summary statistics for the 817 survey respondents. As in the overall administrative data set, survey respondents from Plans A and B, the automatic enrollment plans, have a lower mean salary than the voluntary enrollment plan, Plan C. Plan C participants, besides having higher wages, also have higher levels of educational attainment: the proportion of post-graduate education is more than double in Plan $\mathrm{C}$ than in Plan A and B, and only 9\% of Plan C respondents have just completed high school (or less), versus $20 \%$ and $37 \%$ in the two automatic enrollment plans.

\section{Table II here}

In implementing the survey, our aim was to reach at least 250 respondents in four categories: in a voluntary or automatic enrollment plan, and participating or not participating. Given the small total number of automatic enrollment non-participants, however, we were able to reach only 62 of such employees. Panel B of Table II presents the number of respondents in each category.

\section{Literacy and Trust Measures}

Our literacy measure is derived from an eight question quiz. Three questions relate to very basic financial concepts: the idea of compounding, the risks of investing in an equity mutual fund, and familiarity with common financial instruments. Five questions are related to 401(k) plan features: whether the employer offers a plan; whether the employee is participating (i.e., whether the participant accurately can recall whether or not he or she is contributing to the plan); whether the employer offers a match; the 
value of the match; and the presence or absence of a loan feature. The full questionnaire and descriptive statistics are included in the Appendix. From the responses, we created a binary measure of literacy based on a mean split (mean=5.6). Participants scoring a six, seven or eight on the quiz are considered part of a "high literacy" group, those scoring from zero to five are considered to be part of a "low literacy" group.

Our trust measure was based on the extent of respondents' agreement or disagreement with the following statement: "For the most part, financial institutions are trustworthy.” Often trust measures in other studies are based on broad statements, such as whether the respondents are trusting of other people. But such instruments have been criticized as being too vague and perhaps unrelated to specific behaviors (Glaeser, Laibson, Scheinkman, and Soutter 2000). Our approach (following Alesina and La Ferrara, 2002) is to focus on trust in financial institutions. ${ }^{11}$ As with our financial literacy indicator, we created a binary measure of trust. "Low trust” respondents are those who disagree or strongly disagree with the idea of trusting financial institutions; "high trust" are all others. ${ }^{12}$

Table III provides summary statistics for our literacy and trust measures. As shown in Panel A, 58\% of the survey respondents are in the high literacy group, and 86\% in the high trust group. High literacy is much more common among voluntary enrollment participants than automatic enrollment participants (78\% v. 57\%). Meanwhile, low levels of literacy are more common among quitters of automatic enrollment plans than non-joiners of voluntary enrollment plans (73\% versus 57\%). Interestingly, when comparing participants to non-participants, regardless of the plan type, a majority of participants are in the high literacy category while a majority of the 
non-participants are in the low literacy category. The trust measure is more closely related to non-saving behavior under automatic enrollment. Twenty-six percent of those who quit automatic enrollment were low trust individuals, versus $15 \%$ of employees who failed to join a voluntary plan. ${ }^{13}$

\section{Table III}

Panel B of Table III analyzes financial literacy and trust measures by level of educational attainment and salary. As might be expected, a high school education (or less) appears somewhat related to low levels of literacy and trust. Low levels of literacy and trust are also more common in the bottom half of the income distribution in our sample. That said, our literacy and trust measures are not strictly a function of education and income. Nearly one-third of respondents who have completed some graduate work (beyond 4-year college) have low levels of literacy; and over one in 10 of respondents in the top quartile of salary has low levels of trust in financial institutions. ${ }^{14}$

Table IV further decomposes our literacy and trust measures by education, salary and saving behavior. Panel A reports the percent of survey respondents with low levels of financial literacy; Panel B, the percent of respondents with low trust. Panel A demonstrates a powerful relationship of low levels of financial literacy to saving behavior. Among those with a high school (or less) education, 79\% of quitters (nonparticipants) in automatic enrollment plans have low levels of literacy, versus $40 \%$ of those who voluntarily joined a savings plan. There are similar effects by salary. Seventy-six percent of the bottom-quartile salary earners who quit their automatic 401(k) plan had low literacy, versus only $20 \%$ of the bottom-quartile salary earners who joined their voluntary 401(k) plan. These statistics also suggest that education, salary and 
financial literacy are imperfectly related. ${ }^{15}$ The effects in Panel B for low trust are somewhat different. Overwhelmingly the largest low-trust groups are, first, quitters (nonparticipants) of automatic enrollment plans, generally across all education levels and most salary levels; and second, non-joiners (non-participants) of voluntary enrollment plans with a high school education or less.

Table IV here

\section{Econometric Analysis}

The descriptive statistics in the previous section suggest that both literacy and trust may play a role in 401(k) savings decisions. In this section, we assess the relationship between the employee plan participation decision using several probit regressions relating an employee's plan participation decision to a variety of demographic measures and our trust and literacy indicators. Specifically our models are of the following form:

$$
\text { PARTICIPANT }_{i}=\beta_{0}+\beta_{1} E_{i}+\beta_{2} \text { LOWLIT }_{i}+\beta_{3} \text { LOWTRUST }_{i}+\varepsilon_{i}
$$

In Equation (1), the dependent variable PARTICIPANT equals 1 if the ith eligible employee is participating in the plan, otherwise $0 ; E E_{i}$ is a vector of demographic variables for the ith eligible employee in our survey, which includes age, salary, marital status, number of dependents, job tenure and race/ethnicity; and LOWLIT and LOWTRUST are dummy variables indicating whether the participant fell into the low literacy and low trust categories, respectively. We pool respondents from Plans A and B into a single regression for automatic enrollment; the respondents from Plan C are in a separate regression for voluntary enrollment. We do not pool all the plans together 
because the binary choice to participate is fundamentally different (either opt in or opt out) depending on the enrollment method.

In Table V, the first set of results is for a standard specification of 401(k) plan participation based on prior studies. The coefficients and their standard errors are shown. Not surprisingly, in the standard specification for voluntary enrollment, we find based on the marginal effects (not reported in the table) we calculated that a salary increase, job tenure increase and marriage raise the probability of participation in a voluntary plan, while lower levels of education and additional dependent children reduce the probability of participation. ${ }^{16}$ Meanwhile, in the standard specification model under automatic enrollment, none of these demographic variables has a positive relationship to plan participation. This result is consistent with the finding from prior research that automatic enrollment tends to equalize savings behavior across various demographic groups.

\section{Table V here}

Two additional specifications add literacy and trust as separate explanatory variables. In the standard specification with our literacy measure under voluntary enrollment, several demographic variables - high school education, job tenure, marriage and number of dependents - remain significant. The new literacy variable is economically meaningful and significant, and the calculated marginal effect indicates that an employee with low literacy is $29 \%$ less likely to participate—a very sizeable effect. Meanwhile, under the same specification with automatic enrollment, the demographic effects remain insignificant and only our literacy indicator remains meaningful, with a low literacy employee $15 \%$ less likely to remain in the plan. Under both voluntary and 
automatic enrollment models, the addition of the new literacy variable improves the regressions pseudo- $R^{2}$ s over the standard specification without those variables.

The addition of the trust variable to the standard specification produces somewhat different results. In our analysis, trust is not important to savings decisions under voluntary enrollment but is very important under automatic enrollment. Someone with low trust is $20 \%$ less likely to remain in an automatic enrollment plan. These results are consistent with a theory that procrastination as an explanatory factor may be overshadowing the influence of trust in voluntary enrollment settings. However, once the procrastination effect is largely offset with the introduction of automatic enrollment, trust surfaces as an important explanatory variable of the remaining variation in savings behavior. This explanation needs to be tested with more data from additional plans. However, it is a noteworthy result because it does show that trust can be an important factor in savings and investment decisions related to retirement.

Our final empirical specification includes both trust and literacy measures. Interestingly, the marginal effects of the two measures are relatively stable across specifications. Please refer to Figure I for a graphical depiction of selected marginal effects calculated from the final specification. Literacy is important in both types of enrollment. Low literacy individuals are $30 \%$ less likely to participate under voluntary enrollment and $13 \%$ less likely to participate under automatic enrollment. The effect of literacy in a voluntary plan is quite substantial compared to income. For example, an increase of $\$ 10,000$ in income would only raise the probability of participation by $2 \%$ in a voluntary enrollment setting and this effect is only significant at the $10 \%$ level. In automatic enrollment, trust again comes to the forefront in explaining quitting behavior, 
as trust levels decrease, the probability of participation decreases by $15 \%$. Interestingly, these marginal effects are relative to an individual with high literacy and high trust. If we recalculate the marginal effect for the same person but give them low literacy characteristics, the influence of low trust levels increases. For this individual, as trust levels decrease, the probability of participation decreases by $23 \%$. Finally, education, which is distinct from financial literacy, is a separate and significant explanatory variable under voluntary enrollment. But consistent with the notion that automatic enrollment reduces significant demographic variation in savings behavior, education does not appear to be significant in the automatic enrollment specification.

Our findings suggest a multi-faceted model of employee saving in 401(k) plans, consistent with models of neo-classical decision agents, information costs, and behavioral biases. Our final specification confirms both a neoclassical model for voluntary enrollment, linking saving behavior of various demographic variables such as salary, as well as a behavioral model, in which automatic enrollment eliminates much of these demographic variations. Beyond these explanations, however, our results underscore the importance of qualitative measures such as literacy and trust in explaining retirement savings behavior. The importance of literacy as an explanatory variable is consistent with a model of decision agents constrained by access to appropriate financial information. The significance of trust confirms a new dimension of decision-making in 401(k) savings choices that may or may not be rational, namely, a lack of trust in financial institutions, particularly but not exclusively among employees with lower wages and lower levels of educational attainment. 


\section{Conclusions}

Prior research on 401(k) savings behavior has focused on the importance of neoclassical models in explaining variation in saving behavior, or on behavioral biases such as procrastination as impediments to rational decision-making. Automatic enrollment in particular has emerged as a response by employers and policymakers to findings of employee procrastination in retirement savings. The strategy is being adopted by employers, with active encouragement in the Pension Protection Act of 2006, in an effort to improve savings behavior through default, or reframing effects. This paper highlights the importance of two other factors — financial literacy and trust—in 401(k) savings decisions, and assesses their impact depending on whether the decision is framed as a positive (voluntary) or negative (automatic enrollment) one.

In particular, in voluntary savings arrangements, both demographic characteristics and financial literacy play a role in explaining variations in the decision whether to participate in a 401(k) plan. The literacy effects are quite substantial. Low literacy individuals are 30\% less likely to participate in their 401(k) plan; by comparison, an increase in income of $\$ 10,000$ would lead to only a $2 \%$ increase in the probability of participation and this effect is not even statistically significant. In automatic enrollment arrangements, which tend to minimize demographic variations in savings behavior, what stands out is the role of trust in financial institutions along with financial literacy in influencing whether employees will choose to quit such plans. In such plans, the marginal effect of low trust is a $15 \%$ reduction in plan participation; for low literacy, it is 13\%. Our results support both a rational information costs model of decision-makingsome employees are impeded in their decision-making simply by a lack of adequate 
financial information-- and a behavioral bias theory—some employees are influenced substantially by framing. Furthermore, our trust finding demonstrates that some employees may be influenced by the psychological level of trust they have in financial institutions. This finding is new to $401(\mathrm{k})$ research, and may also more broadly influence retirement and other savings behavior.

More broadly, our findings extend the richness of our understanding of the complex factors underlying savings choices. The earliest empirical models of 401(k) saving, focusing exclusively on voluntary savings choices, relied on a neoclassical lifecycle framework, and incorporated such demographic factors such as age and income as important explanatory variables. In subsequent studies of automatic enrollment, this approach was extended to include behavioral biases such as procrastination. Our findings suggest an even more nuanced model. First, models of voluntary savings choice ought to incorporate financial literacy as a separate, and powerful, explanatory variable. And second, even with the introduction of automatic enrollment, which eliminates much demographic variation in savings choices, both low literacy and low trust in financial institutions stand out as critical explanations of non-saving behavior.

On a practical and policy level, our findings underscore the importance of remedial education programs and plan design strategies that focus on raising literacy and trust levels among targeted groups of employees. These efforts seem particularly important in the case of plans adopting automatic enrollment. As automatic enrollment becomes more widespread, plan sponsors and policymakers may come to view enrollment communications and 401(k) literacy programs generally as superfluous, and quitters as purely rational agents making calculated choices about their future. An 
alternative view arising from our study is that plan enrollment communications by employers - and retirement education generally by community groups and the government - becomes even more essential in raising financial literacy levels, and reducing quit rates under automatic enrollment.

Our findings also highlight the need for strategies to bolster trust in financial institutions. These include employers and community groups adopting social marketing approaches, such as electing a plan or retirement savings advocate, introducing a trusted peer program or offering seminars designed to increase understanding and trust of financial institutions. Finally, another possible remedial strategy is to consider changing plan design —in particular, periodically re-enrolling those who quit automatic enrollment arrangements - under the assumptions that financial literacy and trust levels may change over time with learning, and that such employees, if re-enrolled, may choose not to quit the second or third time around.

In summary, what emerges from our findings, and the now extensive body ofprior research, is a complex and nuanced model of $401(\mathrm{k})$ retirement saving. It is no longer sufficient to explain savings behavior in terms of purely neoclassical lifecycle models. Literacy effects appear to be pervasive. Also, even a behaviorally-motivated reframing of savings choices under automatic enrollment while extremely effective still leaves some room for improvement among a vulnerable subset of employees, those exhibiting low literacy and mistrust of financial institutions. Our findings suggest several possible avenues for future research, including the ways in which employers, community groups and governments can effectively improve understanding of basic retirement savings concepts. Additionally, if trust levels in financial institutions drop due to the recent 
economic events, the long-term repercussions may be far-reaching and long lasting.

Therefore, research focusing on how overall trust impacts all financial decisions,

including retirement decision-making, is now even more important and necessary.

\section{Endnotes}

\footnotetext{
${ }^{1}$ Automatic enrollment was first authorized by the US Internal Revenue Service in 1997. The Pension Protection Act of 2006 also included several provisions to encourage its wider adoption.

${ }^{2}$ See Agarwal, Discroll, Gabaix and Laibson (2008) for an illustration of learning and financial decisionmaking.

${ }^{3}$ See Munnell, Sunden and Taylor (2001/2002) and Mitchell, Utkus and Yang (2007) for a review of past

literature.

${ }^{4}$ See Benartzi and Thaler (2007) for a comprehensive overview.

${ }^{5}$ Not all distrust of financial institutions among the poor is irrational. Business Week (Grow, Epstein, Elgin, Der Hovanesian 2007) devoted a cover story to how U.S. companies are actively seeking profits from the poor and not always using fair business practices. The recent subprime lending crisis in the U.S. demonstrates that in many instances poorer individuals may have been misled by financial institutions. Furthermore, Guiso, Sapienza and Zingales' (2008) present a theoretical model of trust that relies on prior beliefs which they argue cannot be irrational. They assert that only beliefs after exposure to information can be irrational, and if the information presented is not trusted, then it cannot be used be used to form beliefs. For some additional background on trust and a survey of the psychology literature as it related to finance please refer to Olsen (2008).

${ }^{6}$ Researchers have also shown that trust can have a positive effect on a company's financial performance and on the macroeconomy. La Porta, Lopez-de-Silanes, Shliefer and Vishny (1997) in particular found that large organizations perform better and have a larger share of the economy when trust levels are higher. Similarly, Knack and Keefer (1997) found that the economy of countries where trust levels are higher grows faster than countries that have lower overall levels of trust.

${ }^{7}$ Administrative data for Plans A and B were collected in June 2006; for Plan C, in May 2006. Data included: age, income, sex and race/ethnicity; contributions for the year; investment holdings and balances; and related plan features. Vanguard (2006) provides descriptive statistics of the overall Vanguard data base from which the three plans were drawn.

${ }^{8}$ All three plans offer the same employer matching contributions; the ability of employees to make "catchup" contributions (after age 50); and the standard immediate vesting of employee contributions. The matching formula and vesting schedule for employer contributions vary somewhat by plan. In terms of investment options, all three plans offer individual fund options ranging from 11 funds to 14 funds. In addition to individual fund choices, Plans B and C also offer pre-mixed life cycle portfolios.

${ }^{9}$ An employee is considered an active participant if they were making positive employee contributions to the plan at the time the administrative data was extracted.

${ }^{10}$ Our sample includes the overwhelming majority of the employees eligible to participate in each plan who were hired after their respective cut-off dates. It excludes employees who had participated in the past year in market research for Vanguard or who previously asked not to be contacted. Although not reported here, the demographic statistics for the entire population of employees are very similar to our sample data. These results are available upon request. The marketing research firm Greenwald Associates conducted the survey.

${ }^{11}$ Alesina and La Ferrara (2002) show that while an average of $40 \%$ of survey respondents report that they trust other people, the percentage drops dramatically when they are asked about their confidence in certain institutions. Specifically, an average of only $27 \%$ of people report having confidence in financial institutions. See also Guiso, Sapienza and Zingales (2008).
} 
${ }^{12}$ All non-respondents to this question were conservatively classified as high trust individuals. As a robustness check, we also excluded this group from the later regression analysis and did not find a qualitatively different result.

${ }^{13}$ Care must be taken when interpreting these statistics because the sample size of the non-participant, automatically enrolled employees is small compared to other groups.

${ }^{14}$ Guiso, Sapienza and Zingales (2008) note that one of the advantages of using trust to predict general stock market participation in their study is that it can explain lack of participation by wealthy individuals. They show a strong positive correlation between the level trust in a country and the level of participation among the top $5 \%$ of the wealth distribution in the same 12 countries.

${ }^{15}$ Using survey data representative of the Dutch population , van Rooij, Lusardi and Alessie (2007) also find that schooling may not be the best proxy for financial literacy.

${ }^{16}$ The marginal effects are relative to a white, married male with a high school education. The salary $(\$ 56,656)$, age (40), job tenure (2.25) and dependents (1) are based on the means for the entire sample. 


\section{Appendix A. Financial Literacy Questionnaire Table}

Table A.1.

\begin{tabular}{|c|c|c|c|c|c|c|}
\hline & & & & & & \\
\hline & & & Automatic & Enrollment & Voluntary & Enrollment \\
\hline $\begin{array}{l}\text { Topic/ Questions (Correct Answer in } \\
\text { Italics and Underlined) }\end{array}$ & Answer & All Respondents & Participants & $\begin{array}{r}\text { Non- } \\
\text { Participants }\end{array}$ & Participants & $\begin{array}{r}\text { Non- } \\
\text { Participants }\end{array}$ \\
\hline Basic Financial Knowledge & & & & & & \\
\hline $\begin{array}{l}\text { 1. If you are saving for a future goal, } \\
\text { it's better to start early. That way } \\
\text { your money earns more and builds } \\
\text { up faster over time. True or False. } \\
\text { (Source: Based on Hilgert, Hogarth }\end{array}$ & Correct & $97 \%$ & $98 \%$ & $92 \%$ & $98 \%$ & $96 \%$ \\
\hline and Beverly (2003)) & Incorrect & $1 \%$ & $0 \%$ & $3 \%$ & $1 \%$ & $2 \%$ \\
\hline & Not Sure & $2 \%$ & $2 \%$ & $5 \%$ & $1 \%$ & $3 \%$ \\
\hline $\begin{array}{l}\text { 2. If you were to invest } \$ 1,000 \text { in a } \\
\text { stock mutual fund, it would be } \\
\text { possible to have less than } \$ 1,000 \\
\text { when you withdraw your money. } \\
\text { True or False. (Source: John }\end{array}$ & Correct & $67 \%$ & $62 \%$ & $63 \%$ & $76 \%$ & $63 \%$ \\
\hline Hancock Financial Services (2002)) & Incorrect & $13 \%$ & $12 \%$ & $16 \%$ & $11 \%$ & $15 \%$ \\
\hline & Not Sure & $20 \%$ & $26 \%$ & $21 \%$ & $13 \%$ & $22 \%$ \\
\hline $\begin{array}{l}\text { 3. In which ONE of the following } \\
\text { products would you choose to invest } \\
\text { your money for the highest expected } \\
\text { long term growth? (Answer Choices: } \\
\text { Stock Mutual Fund, Savings }\end{array}$ & Correct & $69 \%$ & $69 \%$ & $50 \%$ & $79 \%$ & $64 \%$ \\
\hline Account, CD, Insurance Policy, Don't & Incorrect & $19 \%$ & $20 \%$ & $32 \%$ & $14 \%$ & $22 \%$ \\
\hline 2004 Jump $\$$ tart Questionnaire) & Not Sure & $11 \%$ & $11 \%$ & $18 \%$ & $7 \%$ & $14 \%$ \\
\hline Plan Knowledge ${ }^{\star}$ & & & & & & \\
\hline $\begin{array}{l}\text { 4. Does your company currently offer } \\
\text { a retirement plan? Yes or No. }\end{array}$ & & & & & & \\
\hline & Correct & $98 \%$ & $99 \%$ & $97 \%$ & $99 \%$ & $96 \%$ \\
\hline & Incorrect & $1 \%$ & $1 \%$ & $0 \%$ & $1 \%$ & $1 \%$ \\
\hline & Not Sure & $1 \%$ & $0 \%$ & $3 \%$ & $1 \%$ & $3 \%$ \\
\hline $\begin{array}{l}\text { 5. Do you currently contribute part of } \\
\text { your paycheck to your company's } \\
\text { retirement savings plan? Yes or No. } \\
\text { (Non-Participants: No, Participants: } \\
\text { Yes) }\end{array}$ & Correct & $87 \%$ & $96 \%$ & $74 \%$ & $99 \%$ & $67 \%$ \\
\hline & Incorrect & $12 \%$ & $3 \%$ & $18 \%$ & $1 \%$ & $31 \%$ \\
\hline & Not Sure & $1 \%$ & $0 \%$ & $8 \%$ & $0 \%$ & $2 \%$ \\
\hline $\begin{array}{l}\text { 6. Some employers offer a matching } \\
\text { contribution in their retirement } \\
\text { savings plan. With a matching } \\
\text { contribution if you put in your } \\
\text { money, the employer also adds }\end{array}$ & Correct & $90 \%$ & $94 \%$ & $76 \%$ & $96 \%$ & $83 \%$ \\
\hline $\begin{array}{l}\text { some money to your account. Does } \\
\text { your plan offer matching }\end{array}$ & Incorrect & $6 \%$ & $3 \%$ & $15 \%$ & $3 \%$ & $9 \%$ \\
\hline contributions? Yes or No. & Not Sure & $4 \%$ & $2 \%$ & $10 \%$ & $1 \%$ & $8 \%$ \\
\hline $\begin{array}{l}\text { 7. What is your employer's match? } \\
\text { (Responses were recorded verbatim } \\
\text { and two independent researchers } \\
\text { coded whether they were accurate } \\
\text { or not) }\end{array}$ & Correct & $9 \%$ & $5 \%$ & $0 \%$ & $16 \%$ & $7 \%$ \\
\hline & Incorrect & $58 \%$ & $66 \%$ & $50 \%$ & $63 \%$ & $45 \%$ \\
\hline & Not Sure & $33 \%$ & $29 \%$ & $50 \%$ & $21 \%$ & $48 \%$ \\
\hline 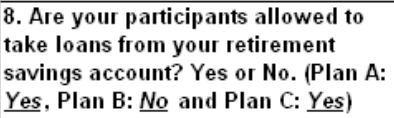 & & & & & & \\
\hline & Correct & $42 \%$ & $32 \%$ & $27 \%$ & $56 \%$ & $41 \%$ \\
\hline & Incorrect & $16 \%$ & $26 \%$ & $31 \%$ & $8 \%$ & $11 \%$ \\
\hline & Not Sure & $42 \%$ & $42 \%$ & $42 \%$ & $36 \%$ & $48 \%$ \\
\hline & & & & & & \\
\hline $\begin{array}{l}\text { All three basic financial knowledge } \\
\text { questions correct }\end{array}$ & & $49 \%$ & $46 \%$ & $26 \%$ & $62 \%$ & $42 \%$ \\
\hline $\begin{array}{l}\text { All five plan knowledge questions } \\
\text { correct }\end{array}$ & & $5 \%$ & $2 \%$ & $0 \%$ & $12 \%$ & $1 \%$ \\
\hline All eight questions correct & & $4 \%$ & $1 \%$ & $0 \%$ & $9 \%$ & $0 \%$ \\
\hline
\end{tabular}

"Questions 5-8 asked only of those responding "yes" to question 4. Responses to questions 5-8 for this small subset were coded incorrect. Percentages may not sum to 100 percent due to rounding. 


\section{References}

Agarwal, Sumit, John C. Driscoll, Xavier Gabaix, and David I. Laibson , "The Age of Reason: Financial Decisions Over the Lifecycle," SSRN Working Paper, (2/11/2008). Available at SSRN: http://ssrn.com/abstract=973790.

Agnew, Julie R. and Lisa R. Szykman., “Asset Allocation and Information Overload: The Influence of Information Displays,” Journal of Behavioral Finance, 6(2), (2005),pp. 57-70.

Alesina, Alberto and Eliana La Ferrara “Who Trusts Others?” Journal of Public Economics, 85, (2002),pp. 207-234.

Benartzi, Shlomo and Richard H. Thaler. "Heuristics and Biases in Retirement Savings Behavior,” Journal of Economic Perspectives, 21, 3, (2007), pp. 81-104.

Bernheim, B. Douglas and Daniel M. Garrett. "The Determinants and Consequences of Financial Education in the Workplace: Evidence from a Survey of Households,” NBER Working Paper 5667.

Bertrand, Marianne, Sendhil Mullainathan, and Eldar Shafir. "Behavioral Economics and Marketing in Aid of Decision Making Among the Poor," Journal of Public Policy and Marketing, 25, 1, (2006), pp. 8-23.

Chan, Sewin and Ann Huff Stevens. "What You Don’t Know Can’t Help You: Pension Knowledge and Retirement Decision Making,” Working Paper, New York University, 2006.

Choi, James J, David Laibson and Brigitte C. Madrian. "\$100 Bills on the Sidewalk: Suboptimal Saving in 401(k) Plans,” Harvard Working Paper, 2005.

Choi, James J., David Laibson, Brigitte C. Madrian and Andrew Metrick. "Saving for Retirement on the Path of Least Resistance." In Behavioral Public Finance: Toward a New Agenda, Ed McCaffrey and Joel Slemrod, eds. New York: Russell Sage Foundation, (2006), pp. 304-351.

Duflo, Esther and Emmanuel Saez, "The Role of Information and Social Interactions in Retirement Plan Decisions: Evidence from a Randomized Experiment” Quarterly Journal of Economics 118, 3, (2003), 815-842.

Glaeser, Edward L., David I. Laibson, Jose A. Scheinkman and Christine L. Soutter. "Measuring Trust," The Quarterly Journal of Economics, 115, 3, (2000), pp. 811846.

Grow, Brian, Keith Epstein, Ben Elgin and Mara Der Hovanesian. “The Poverty Business; Inside U.S. Companies' Audacious Drive to Extract More Profits from the Nation’s Working Poor,” BusinessWeek, (21 May 2007). 
Guiso, Luigi, Paola Sapienza, and Luigi Zingales. “Trusting the Stock Market,” The Journal of Finance, LXIII, 6, (2008), 2557-2600.

Hilgert, Marianne A., Jeanne M. Hogarth and Sondra G. Beverly. "Household Financial Management: The Connection between Knowledge and Behavior," Federal Reserve Bulletin, (July 2003), Available at: http://www.federalreserve.gov/pubs/bulletin/2003/0703lead.pdf

John Hancock Financial Services. "Insight Into Participant investment, Knowledge and Behavior," Eighth Defined Contribution Survey, (2002).

2004 Jump\$tart Survey of Personal Financial Literacy Among High School Students. Coalition website: http://www.jumpstart.org/index.cfm.

Knack, Stephen and Philip Keefer. "Does Social Capital Have an Economic Payoff? A Cross-Country Investigation,” The Quarterly Journal of Economics, 112, 4, (1997), pp. 1251-1288.

LaPorta, Rafael, Florencio Lopez-de-Silanes, Andrei Shliefer, and Robert W. Vishny. "Trust in Large Organizations," The American Economic Review. 87, 2, (1997), pp. 333-338.

List, John A. "Neoclassical Theory Versus Prospect Theory: Evidence from the Marketplace,” Econometrica, 72, 2, (2004), pp. 615-625.

Lusardi, Annamaria and Olivia S. Mitchell. "Financial Literacy and Planning: Implications for Retirement Wellbeing,” Working Paper, Dartmouth College, 2006.

Madrian, Brigitte C. and Dennis F. Shea. "The Power of Suggestion: Inertia in 401(k) Participation and Savings Behavior,” Quarterly Journal of Economics 116, , (2001), pp. 1149-1525.

Mitchell, Olivia S., Stephen P. Utkus and Tongxuan (Stella) Yang. "Turning Workers into Savers? Incentives, Liquidity and Choice in 401(k) Plan Design,” National Tax Journal, LX, 3, (2007), pp. 469-489.

Moore, Danna. Survey of Financial Literacy in Washington State: Knowledge, Behavior, Attitudes, and Experiences. Social and Economic Sciences Research Center Technical Report 03-39, 2003.

Munnell, Alicia H., Annika Sunden, and Catherine Taylor. "What Determines 401(k) Participation and Contributions?” Social Security Bulletin, 64 (3): 64-76. 
Nessmith, William E., Stephen P. Utkus and Jean A. Young, (2007), "Measuring the Effectiveness of Automatic Enrollment," Vanguard Center for Retirement Research, (2001/2002), www.vanguard.com/retirementresearch.

Nyce, Steven A. "The Importance of Financial Communications for Participation Rates and Contribution Levels in 401(k) Plans," Wharton Pension Research Council Working Paper 2005-03. Wharton School, University of Pennsylvania, 2005. www.pensionresearchcouncil.org.

Olsen, Robert A. "Trust as Risk and the Foundation of Investment Value," Journal of Socio-Economics, 37, (2008), 2189-2200.

Sethi-Iyengar, Sheena, Gur Huberman and Wei Jiang. "How Much Choice is Too Much? Contributions to 401(k) Retirement Plans,” In Pension Design and Structure: New Lessons From Behavioral Finance, Edited by Olivia S. Mitchell and Stephen P. Utkus, Oxford University Press, Oxford, United Kingdom, (2004), pp.83-95.

Szykman, L., Rahtz, D. R., Plater, M and Goodwin, G., "Living on the Edge: Financial Services for the Lower Socio-Economic Strata.” Working Paper, The College of William and Mary, (2005).

van Rooij, Maarten, Annamaria Lusardi and Rob Alessie. "Financial Literacy and Stock Market Participation.” Working Paper 2007-162, Michigan Retirement Research Center, 2007.

Vanguard . How America Saves 2006: A Report on Vanguard 2005 Defined Contribution Plan Data, (2007), www.vanguard.com/retirementresearch. 


\section{Table I: Plan and Employee Characteristics}

This table reports general statistics for the all the plan participants, including survey respondents and nonrespondents. In addition, it includes the type of enrollment each plan uses and the cutoff date for the data collection.

\begin{tabular}{|l|r|r|r|r|}
\hline Plan & Plan A & Plan B & Plan C & All \\
\hline Type of Enrollment & Automatic & Automatic & Voluntary & \\
\hline Cutoff Date & $7 / 1 / 2003$ & $1 / 1 / 2001$ & $1 / 1 / 2001$ & \\
\hline & & & & \\
\hline Eligible New Hires & 1,270 & 2,328 & 5,925 & 9,523 \\
\hline New Hire Participation Rate & $84 \%$ & $78 \%$ & $64 \%$ & $70 \%$ \\
\hline Mean Salary & $\$ 37,994$ & $\$ 34,383$ & $\$ 69,803$ & $\$ 56,934$ \\
\hline
\end{tabular}




\section{Table II: Survey Respondents Characteristics}

Panel A reports important demographic statistics for each plan and all the plans combined ("Total” column on the far right) for respondents only. Panel B breaksdown the number of respondents for each participant status/plan type category.

Panel A: Demographic Characteristics

\begin{tabular}{|c|c|c|c|c|}
\hline Plan & Plan A & Plan B & Plan C & Total \\
\hline Type of Enrollment & Automatic & Automatic & Voluntary & All \\
\hline Survey Sample Size (N) & 116 & 199 & 502 & 817 \\
\hline$\%$ of Eligible New Hires & $9 \%$ & $9 \%$ & $8 \%$ & $9 \%$ \\
\hline Mean Age & 41 & 40 & 40 & 40 \\
\hline Mean Salary & $\$ 35,784$ & $\$ 44,019$ & $\$ 66,463$ & $\$ 56,656$ \\
\hline Mean Tenure (years as of $6 / 30 / 2006$ ) & 1.52 & 3.00 & 2.12 & 2.25 \\
\hline \multicolumn{5}{|l|}{ Sex } \\
\hline Female & $22 \%$ & $26 \%$ & $31 \%$ & $29 \%$ \\
\hline Male & $78 \%$ & $74 \%$ & $69 \%$ & $71 \%$ \\
\hline Missing & $0 \%$ & $0 \%$ & $0 \%$ & $0 \%$ \\
\hline \multicolumn{5}{|l|}{ Ethnic Group } \\
\hline White & $85 \%$ & $80 \%$ & $78 \%$ & $79 \%$ \\
\hline Black/African-American & $6 \%$ & $9 \%$ & $4 \%$ & $6 \%$ \\
\hline Hispanic & $6 \%$ & $5 \%$ & $4 \%$ & $4 \%$ \\
\hline Other / missing & $3 \%$ & $7 \%$ & $14 \%$ & $10 \%$ \\
\hline \multicolumn{5}{|l|}{ Married } \\
\hline No & $25 \%$ & $34 \%$ & $38 \%$ & $35 \%$ \\
\hline Yes & $75 \%$ & $66 \%$ & $62 \%$ & $65 \%$ \\
\hline \multicolumn{5}{|l|}{ Dependents } \\
\hline Zero & $35 \%$ & $41 \%$ & $45 \%$ & $42 \%$ \\
\hline One & $22 \%$ & $19 \%$ & $19 \%$ & $19 \%$ \\
\hline Two & $19 \%$ & $23 \%$ & $25 \%$ & $23 \%$ \\
\hline Three & $16 \%$ & $12 \%$ & $9 \%$ & $10 \%$ \\
\hline More than Three & $6 \%$ & $6 \%$ & $3 \%$ & $5 \%$ \\
\hline Missing & $1 \%$ & $0 \%$ & $0 \%$ & $0 \%$ \\
\hline \multicolumn{5}{|l|}{ Education } \\
\hline High School & $20 \%$ & $37 \%$ & $9 \%$ & $18 \%$ \\
\hline Some College & $38 \%$ & $28 \%$ & $23 \%$ & $26 \%$ \\
\hline College & $31 \%$ & $25 \%$ & $40 \%$ & $35 \%$ \\
\hline Post Graduate Work or Degree & $11 \%$ & $10 \%$ & $27 \%$ & $21 \%$ \\
\hline Refused & $0 \%$ & $1 \%$ & $0 \%$ & $0 \%$ \\
\hline
\end{tabular}

Panel B. Number of Employees by Participation Status and Plan Type

\begin{tabular}{|c|c|c|c|}
\hline & Participant & Non-Participan & Total \\
\hline Automatic & 253 & 62 & 315 \\
\hline Voluntary & 275 & 227 & 502 \\
\hline Total & 528 & 289 & 817 \\
\hline
\end{tabular}




\section{Table III: Financial Literacy and Trust Measures by Participation Status, Plan \\ Type, Education and Salary}

These tables breakdown the percentage of the sample in literacy and trust categories by plan type, participation status, education and salary. Individuals with low literacy answered 5 or less questions correct on the literacy test. Individuals with low trust either strongly disagreed or disagreed to the statement "For the most part, financial institutions are trustworthy." Sample sizes of each category are reported in the far right column.

\begin{tabular}{|c|c|c|c|c|c|c|}
\hline \multirow{3}{*}{\multicolumn{2}{|c|}{$\begin{array}{l}\text { Panel A: Financial Literacy } \\
\text { Saving behavior and type } \\
\text { of enrollment }\end{array}$}} & & & & & \\
\hline & & \multicolumn{2}{|c|}{ Literacy } & \multicolumn{2}{|c|}{ Trust } & \multirow{3}{*}{$\begin{array}{c}\mathbf{N} \\
817 \\
\end{array}$} \\
\hline & & \multirow{2}{*}{$\begin{array}{l}\text { Low } \\
42 \% \\
\end{array}$} & \multirow{2}{*}{$\begin{array}{l}\text { High } \\
58 \% \\
\end{array}$} & \multirow{2}{*}{$\begin{array}{l}\text { Low } \\
14 \% \\
\end{array}$} & \multirow{2}{*}{$\begin{array}{l}\text { High } \\
86 \% \\
\end{array}$} & \\
\hline All & & & & & & \\
\hline \multicolumn{7}{|c|}{ Participants } \\
\hline \multicolumn{2}{|c|}{ Automatic Enrollment } & $43 \%$ & $57 \%$ & $12 \%$ & $88 \%$ & 253 \\
\hline \multicolumn{2}{|r|}{ Voluntary Enrollment } & $22 \%$ & $78 \%$ & $11 \%$ & $89 \%$ & 275 \\
\hline \multicolumn{7}{|c|}{ Non-participants } \\
\hline \multirow{2}{*}{\multicolumn{2}{|c|}{$\begin{array}{l}\text { Automatic Enrollment } \\
\text { Voluntary Enrollment }\end{array}$}} & $73 \%$ & $27 \%$ & $26 \%$ & $75 \%$ & 62 \\
\hline & & $57 \%$ & $43 \%$ & $15 \%$ & $85 \%$ & 227 \\
\hline
\end{tabular}

Panel B: Financial Literacy and Trust by Education and Salary

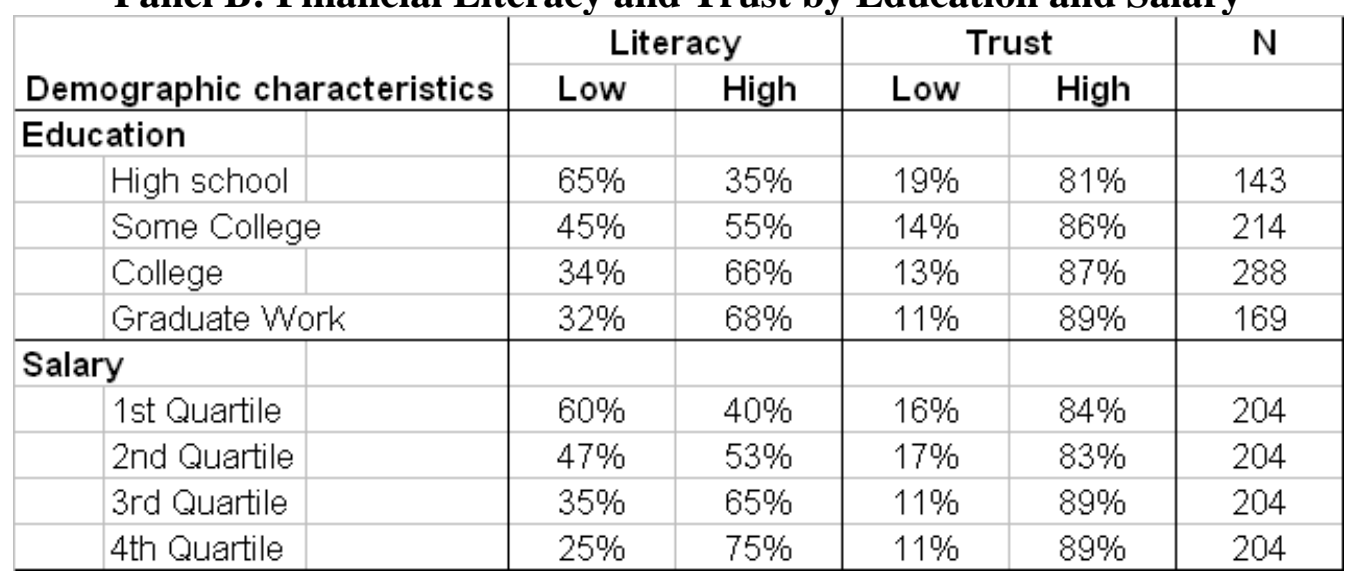

Percentages may not sum to 100 percent due to rounding. 
Table IV: Low Literacy and Low Trust by Various Measures

These tables further refine Table III panel A and Table III B by breaking down each participation/plan type category by either education and or salary. The cells report the percentage of each subcategory that are either low literacy (Panel A) or low trust (Panel B). Individuals with low literacy answered 5 or less questions correct on the literacy test. Individuals with low trust either strongly disagreed or disagreed to the statement "For the most part, financial institutions are trustworthy." Sample sizes of each cell are reported below.

Panel A: Respondents with Low Level of Financial Literacy

\begin{tabular}{|c|c|c|c|c|}
\hline & Non-pa & icipants & Parti & pants \\
\hline $\begin{array}{l}\text { Demogra } \\
\text { character }\end{array}$ & $\begin{array}{l}\text { Automatic } \\
\text { enrollment }\end{array}$ & $\begin{array}{l}\text { Voluntary } \\
\text { enrollment }\end{array}$ & $\begin{array}{l}\text { Automatic } \\
\text { enrollment }\end{array}$ & $\begin{array}{c}\text { Voluntary } \\
\text { enrollment }\end{array}$ \\
\hline Education & & & & \\
\hline High school & $79 \%$ & $69 \%$ & $62 \%$ & $40 \%$ \\
\hline Some Collec & $76 \%$ & $62 \%$ & $40 \%$ & $16 \%$ \\
\hline College & $55 \%$ & $47 \%$ & $36 \%$ & $22 \%$ \\
\hline Graduate W & $50 \%$ & $59 \%$ & $20 \%$ & $22 \%$ \\
\hline Salary & & & & \\
\hline 1st Quartile & $76 \%$ & $71 \%$ & $54 \%$ & $20 \%$ \\
\hline 2nd Quartile & $61 \%$ & $57 \%$ & $44 \%$ & $35 \%$ \\
\hline 3rd Quartile & $80 \%$ & $53 \%$ & $21 \%$ & $25 \%$ \\
\hline 4th Quartile & $100 \%$ & $49 \%$ & $13 \%$ & $14 \%$ \\
\hline
\end{tabular}

Panel B: Respondents with Low Level of Trust

\begin{tabular}{|c|c|c|c|c|}
\hline \multirow[b]{2}{*}{ Demographic characteristics } & \multicolumn{2}{|c|}{ Non-participants } & \multicolumn{2}{|c|}{ Participants } \\
\hline & $\begin{array}{l}\text { Automatic } \\
\text { enrollment }\end{array}$ & $\begin{array}{l}\text { Voluntary } \\
\text { enrollment }\end{array}$ & $\begin{array}{l}\text { Automatic } \\
\text { enrollment }\end{array}$ & $\begin{array}{l}\text { Voluntary } \\
\text { enrollment }\end{array}$ \\
\hline \multicolumn{5}{|l|}{ Education } \\
\hline High school & $29 \%$ & $31 \%$ & $11 \%$ & $10 \%$ \\
\hline Some Colleg & $20 \%$ & $12 \%$ & $11 \%$ & $16 \%$ \\
\hline College & $27 \%$ & $13 \%$ & $16 \%$ & $10 \%$ \\
\hline Graduate Work & $50 \%$ & $13 \%$ & $7 \%$ & $10 \%$ \\
\hline \multicolumn{5}{|l|}{ Salary } \\
\hline 1st Quartile & $24 \%$ & $18 \%$ & $11 \%$ & $20 \%$ \\
\hline 2nd Quartile & $33 \%$ & $18 \%$ & $15 \%$ & $12 \%$ \\
\hline 3rd Quartile & $20 \%$ & $13 \%$ & $11 \%$ & $9 \%$ \\
\hline 4th Quartile & $0 \%$ & $13 \%$ & $4 \%$ & $12 \%$ \\
\hline
\end{tabular}

Sample Sizes: Number of employees represented in each Participation/Plan Type category by Education:

Automatic, Non-Participants [High School: N=24, Some College: N=25, College: N=11, Graduate Work: $\mathrm{N}=2$ ], Voluntary, Non-Participants [High School: $\mathrm{N}=36$, Some College: $N=65$, College: $N=79$, Graduate Work: N=46] Automatic, Participants [High School: N=73, Some College: N=75, College: N=74, Graduate Work: N=30] Voluntary, Participants [High School: N=10, Some College: N=49, College: $\mathrm{N}=124$, Graduate Work: N=91] Number of employees represented in each Participation/Plan Type category by Salary Quartile: Automatic, Non-Participants [1st Quartile: N=37, 2nd Quartile: N=18, 3rd Quartile: N=5, 4th Quartile: N=1 ] Voluntary, Non-Participants [1st Quartile: N=49, 2nd Quartile: N=49, 3rd Quartile: N=68, 4th Quartile: N=61]Automatic, Participants [1st Quartile: N=108, 2nd Quartile: $\mathrm{N}=94$, 3rd Quartile: $\mathrm{N}=28$, 4th Quartile: $\mathrm{N}=23$ ] Voluntary, Participants [1st Quartile: $N=10$, 2nd Quartile: N=43, 3rd Quartile: $N=103$, 4th Quartile: $N=119]$ Percentages may not sum to 100 percent due to rounding. 


\section{Table V: Probit Regressions for Survey Sample}

This table reports the coefficients from a probit regression. The dependent variable is a binary variable that equals one if the employee participated in his 401(k) plan or equals zero if he did not. Ln(Salary) is the natural log of salary measured in dollars. High School, Some College, College are dummy variables for education (omitted category is graduate work). Age is measured in years. Male is a dummy variable that equals one if the employee is male. Married is a dummy variable the equals one if the respondent is married. Number of Dependents is equal to the number of children or elderly living in the household not including the spouse and Job Tenure is the years employed. Low literacy is a dummy variable that equals one if the employee answered 5 or less questions correct on the literacy test. Low trust is equal to 1 if the employee strongly disagrees or disagrees to the statement "For the most part, financial institutions are trustworthy." Race is controlled for with dummy variables. The results are not significant and not reported for space reasons. Robust standard errors are reported in parentheses. ** ,* indicate a significance of $1 \%$ and $5 \%$, respectively.

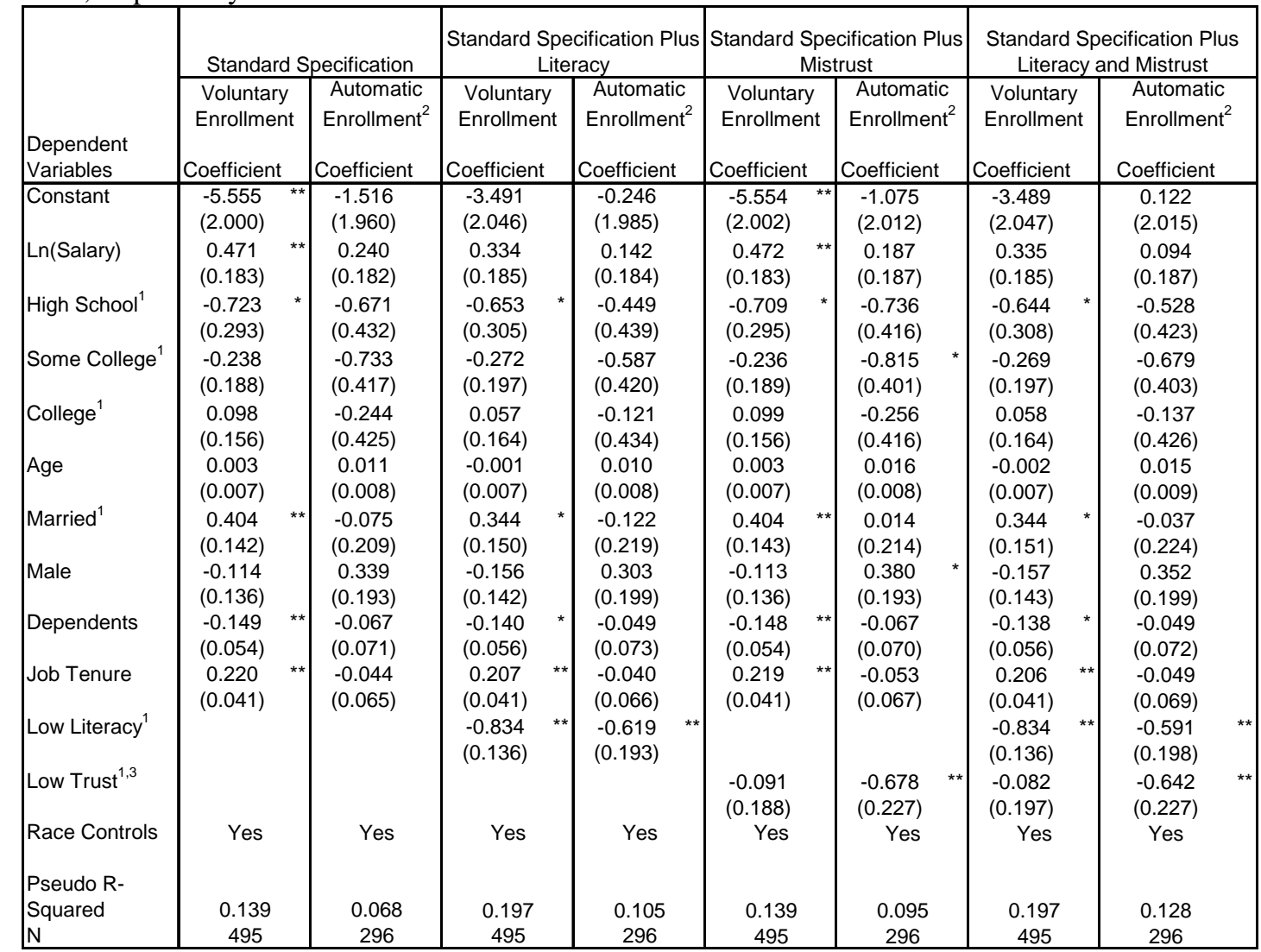

${ }^{1}$ These variables are dummy variables.

${ }^{2}$ In the automatic enrollment plan, eight individuals in the "other" race category perfectly predicted participation and were dropped. Regressions including them as part of the omitted race variable did not qualitatively change the results.

${ }^{3} 20$ individuals who did not answer the trust question were coded as low trust equals zero. Excluding these 20 from the analysis did not qualitatively change the results. 


\section{Figure I: Selected Marginal Effects from Standard Specification Plus Literacy and Trust Probit Regression by Plan Type}

These figures report selected marginal effects from the full probit regression, "Standard Specification Plus Literacy and Trust." The results are calculated at the mean for the continuous variables for the entire sample for all plans combined. The means of the continuous variables are 40 years of age, salary of $\$ 56,656$, job tenure of 2.25 years and 1 dependent. The individual is male and married with a high school education (or less). The individual is in the high literacy and high trust categories. The marginal effects reported for the salary variable show the change in probability for a $\$ 10,000$ increase in salary from the mean. The marginal effect of college represents the change in probability for an individual given a change in education from high school to college level.The marginal effects for dummy variables low literacy and low trust are the change in probability given a change from zero to one of the dummy variable.Bold bars indicate that the underlying coefficients of the marginal effects are significant at least at the $5 \%$ level.** and * indicate significance of $1 \%$ and $5 \%$, respectively. The open bars indicate insignificant coefficients.

Panel A. Under Automatic Enrollment

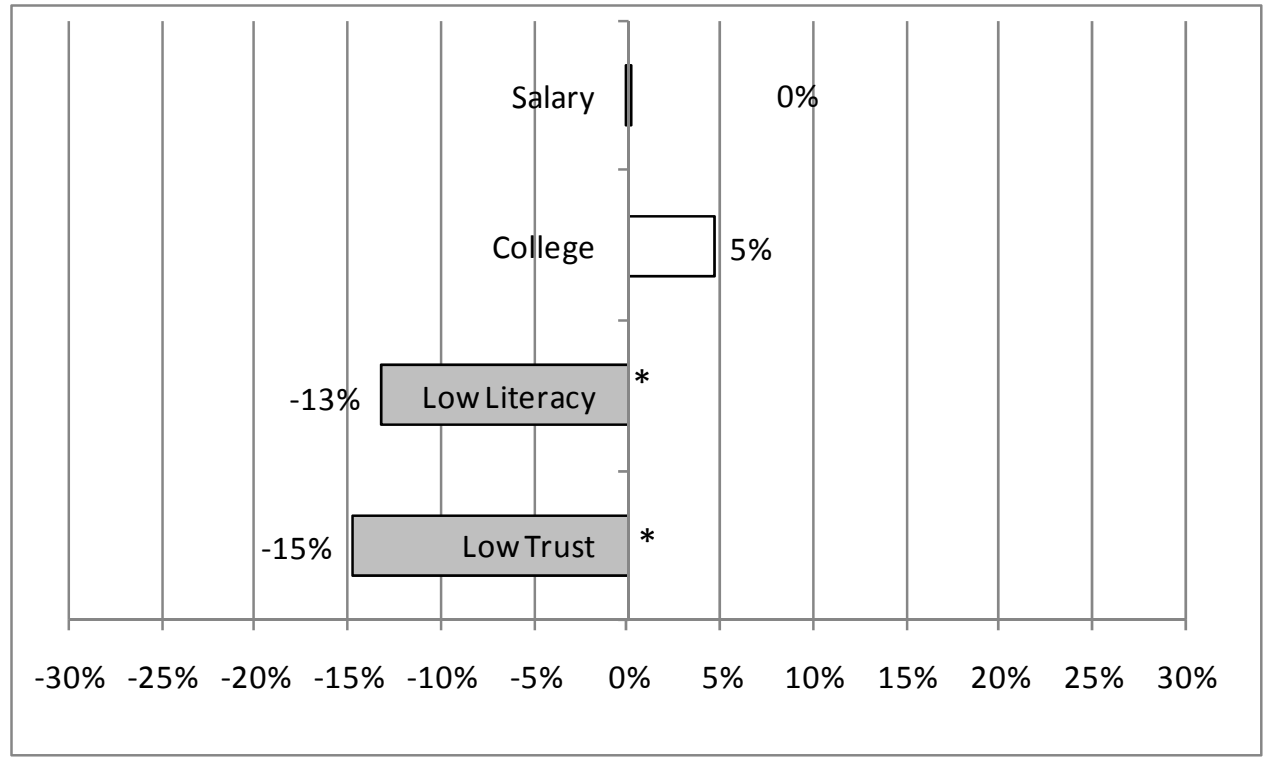

Panel B. Under Voluntary Enrollment

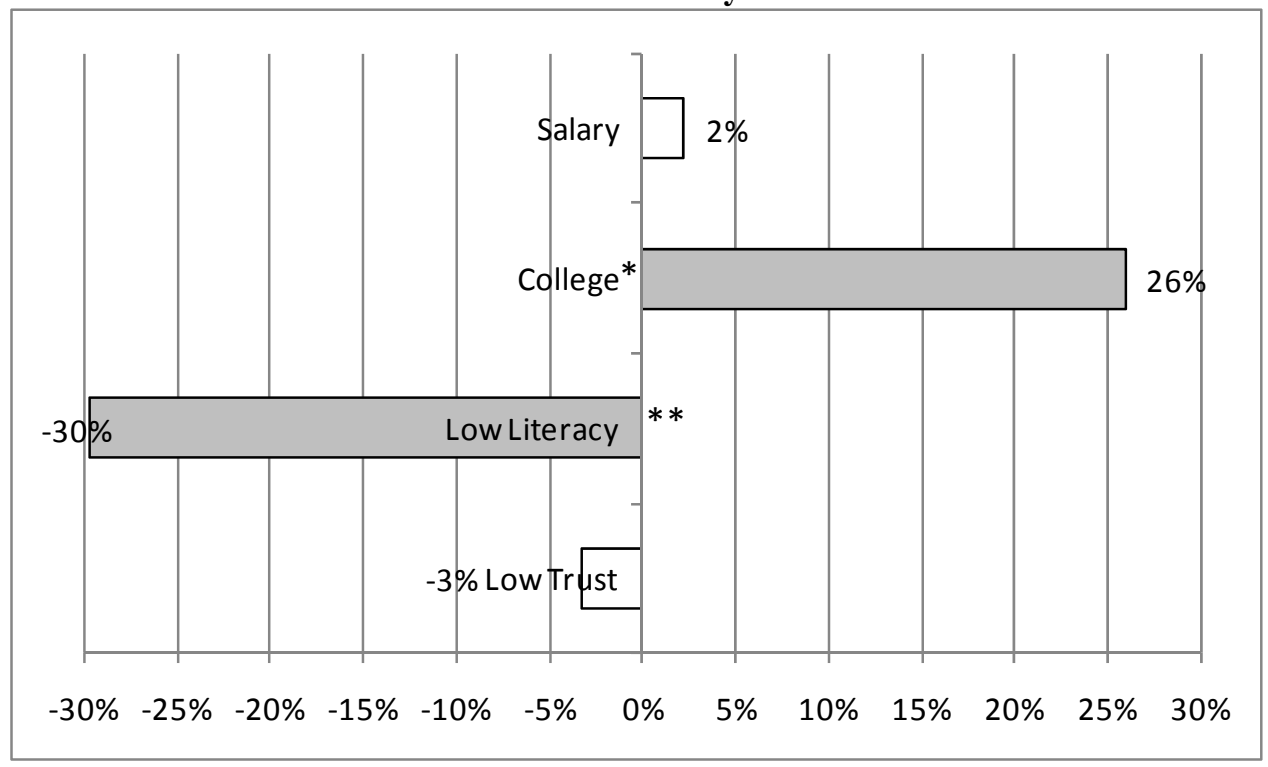




\section{RECENT WORKING PAPERS FROM THE}

\section{CENTER FOR RETIREMENT RESEARCH AT BOSTON COLLEGE}

The Recent Evolution of Pension Funds in the Netherlands: the Trend to Hybrid DB-DC Plans and Beyond

Eduard H.M. Ponds and Bart van Riel, May 2007

Demographic Influences on Saving-Investment Balances in Developing and Developed Economies

Ralph C. Bryant, May 2007

Social Security Spouse and Survivor Benefits for the Modern Family

Melissa M. Favreault and C. Eugene Steuerle, February 2007

How Economic Security Changes During Retirement

Barbara Butrica, February 2007

International Investment for Retirement Savers: Historical Evidence on Risk and Returns

Gary Burtless, February 2007

Job Changes at Older Ages: Effects on Wages, Benefits, and other Job Attributes

Richard W. Johnson and Janette Kawachi, February 2007

Cross-National Comparison of Income and Wealth Status in Retirement: First Results from the Luxembourg Wealth Study (LWS)

Eva Sierminska, Andrea Brandolini and Timothy M. Smeeding, February 2007

Saving and Demographic Change: The Global Dimension

Barry Bosworth and Gabriel Chodorow-Reich, February 2007

The Repeal of the Retirement Earnings Test and the Labor Supply of Older Men Gary V. Engelhardt and Anil Kumar, February 2007

Persistence in Labor Supply and the Response to the Social Security Earnings Test Leora Friedberg and Anthony Webb, December 2006

Annuitized Wealth and Consumption at Older Ages

Barbara A. Butrica and Gordon B.T. Mermin, December 2006

All working papers are available on the Center for Retirement Research website (http://www.bc.edu/crr) and can be requested by e-mail (crr@bc.edu) or phone (617-552-1762). 